\title{
TRANSITIONAL SHELTER FOR DISASTER VICTIMS: BAMBOO CORE AND INCREMENTAL HOUSES
}

\author{
JULISTIONO, Eunike Kristi ${ }^{1}$; MAER, Bisatya Widadya ${ }^{1}$, ARIFIN, Lilianny Sigit ${ }^{1}$ \\ ${ }^{1}$ Department of Architecture, Petra Christian University \\ Jalan Siwalankerto 121-131, Surabaya 60236, INDONESIA \\ Emails: mbm@petra.ac.id; lili@petra.ac.id \\ * Corresponding author: kristi@petra.ac.id
}

\begin{abstract}
Indonesia has experienced many catastrophic disasters since 2004. Tsunami, earthqukes, floods and volcanic eruptions have caused devastated destruction towards houses, land, belongings, and wellfare. In post-disaster recovery process, it is essential to provide a transitional shelter especially for low-income community while preparing the reconstruction of their permanent housing. This paper presents bamboo incremental house as disaster victims' transitional shelter in Jember. An empathic approach was taken in developing the house design, taking into consideration the disaster victims' need, perception, and their economic condition, as well as the local materials, technology and the financial support available.
\end{abstract}

Keywords: Transitional shelter; incremental house; bamboo construction.

\section{INTRODUCTION}

Indonesia is the world's largest archipelago with around 17,500 islands, and located in an extremely volatile part of the world as evidenced by its 76 active volcanoes more than any other countries in the world (Figure 1). Located in a region prone to the floods, earthquakes, tsunamis, and volcanoes, Indonesia has paid a high price for its current mindset towards disaster preparedness. Indonesia is between the world's most active seismic regions. Consequently, Indonesia experiences the most powerful volcanic eruptions and the strongest earthquakes on Earth. The tsunamis caused by the quakes are particularly devastating. Frequently, the natural disaster in Indonesia from 2004-2014 is shown at Table 1.

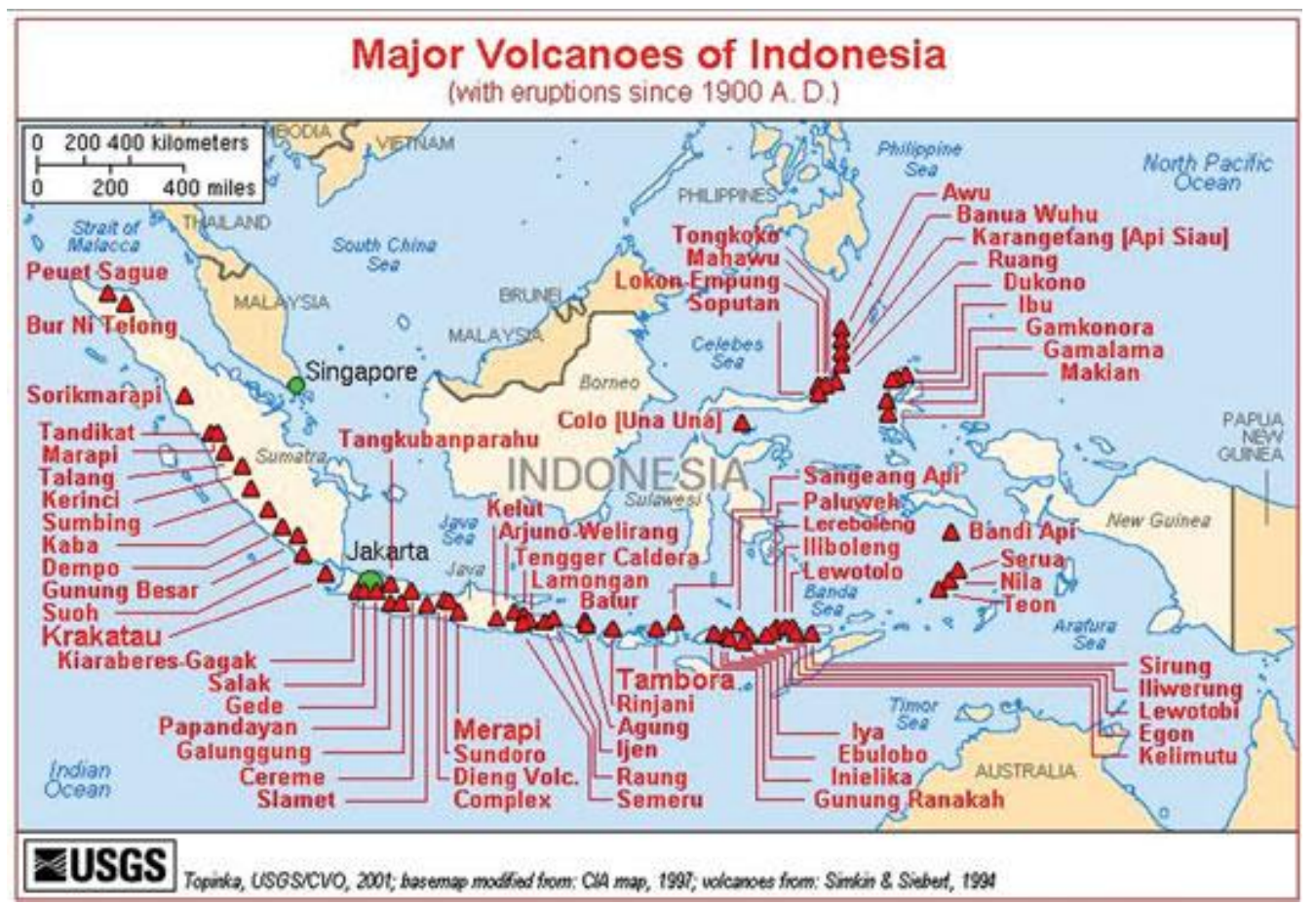

Source: http://www.volcano.si.edu/volcanoes/region 06/halma/ gamkonor/3704gam1.jpg

Figure 1. Map showing major volcanoes of Indonesia 
Table 1. Natural disaster in Indonesia 2004-2014

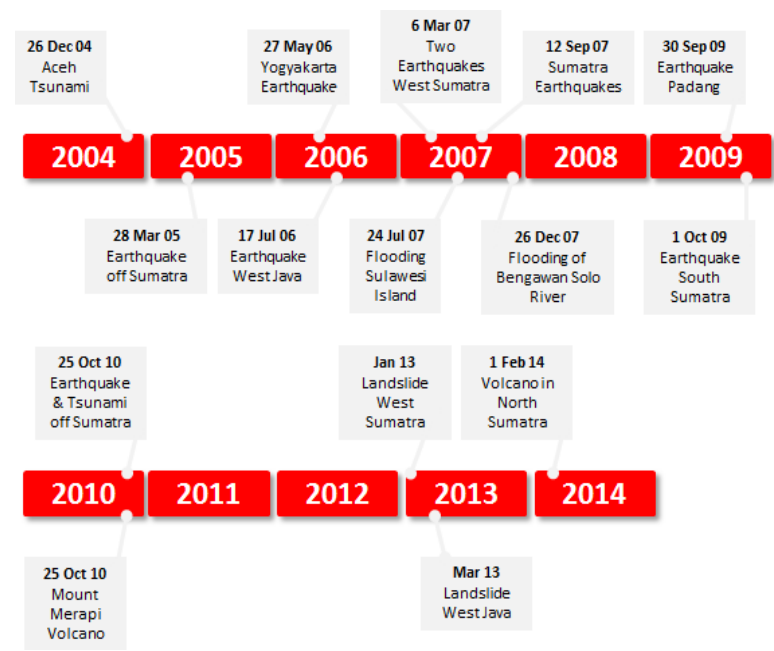

Source: http://www.cpr-indonesia.com/05_Natural_Disasters/ recent_history.html

The most significant structural impact of a disaster is the destruction of households' dwellings. According to Quarantelli (1982), people typically pass through four stages of housing recovery following a disaster. The first stage is emergency shelter, which consists of unplanned and spontaneously sought locations that are intended only to provide protection from earthquakes that might come again. The next step is temporary shelter, which includes food preparation and sleeping facilities. The third step is temporary housing, which allows victims to reestablish household routines in non-preferred locations or structures. The last step is permanent housing, which re-establishes household routines in preferred locations and structures.

Particularly significant are the problems faced by low-income households, because low-income households have fewer resources on which to draw for recovery, they also take longer to transition through the stages of housing. Transitional shelter is needed when buildings are damaged beyond habitability. Actually, there is no standard for transitional shelter design. Standards should be agreed upon, with participation from the affected population, which are appropriate for each beneficiary group. Standards should consider the implication of local hazards, climate, available labour and skills, available material, traditional building practices, cultural requirements, social and household activities.

The transitional shelter approach adds to other successful response approaches, such as core housing and semi-permanent housing, to broaden the range of options for governments and humanitarian stakeholders to support populations affected by disasters and conflicts. Moreover, the transitional shelter approach has been adopted by numerous humanitarian agencies, including the International Organization for Migration and has sheltered many millions of people worldwide who have faced challenges in achieving reconstruction and recovery after disasters and conflicts.

Transitional shelter can reduce the vulnerability of the affected population and contribute to disaster risk reduction by using site selection, site preparation, shelter design and construction as a platform for communicating hazard resilient techniques and best practice and by building capacity within the affected population. Transitional shelter is an incremental process that supports the shelter of families affected by conflicts and disasters, as they seek to maintain alternative options for their recovery.

The following sections describe the pilot project of the transitional shelter model with incremental housing design using bamboo as one of local material in Jember, East Java. This project is designed as a transitional shelter for disaster victims initiated by PMI (Indonesian Red Cross Organization) in cooperation with Department of Architecture, Petra Christian University.

\section{TRANSITIONAL SHELTER}

Disaster brings enormous impacts on the life of the victims not only physically but also mentally and psychologically. Most disasters bring grief towards the victims, taken away their belongings, their houses or even their family members. Thus, a fast recovery process is preferable to minimize the disaster impacts and lessen the suffering of the disaster victims.

In the event of a disaster, such as an earthquake or a volcanic eruption, an emergency shelter is urgent for the victims' survival, it usually refers to a place where the disaster victims can be protected during the disaster. Differ from an emergency shelter, a temporary shelter is more than just taking shelter elsewhere during the emergency (Quarantelli, 1982), it involves short-term accommodation and food supply for the victims. Example of temporary shelter for disaster victims is shown in Figure 2.

However, the main challenge in post-disaster recovery process after a disaster is the planning of transitional houses and the rebuilding of permanent houses. Transitional houses are built in a certain location, and the disaster victims can stay in these houses for some period of time, start over their daily life before they can move back to their own houses. Even though a transitional house will accommodate the revitalisation of the victims' life for some period, but a more permanent solution should be prepared. 


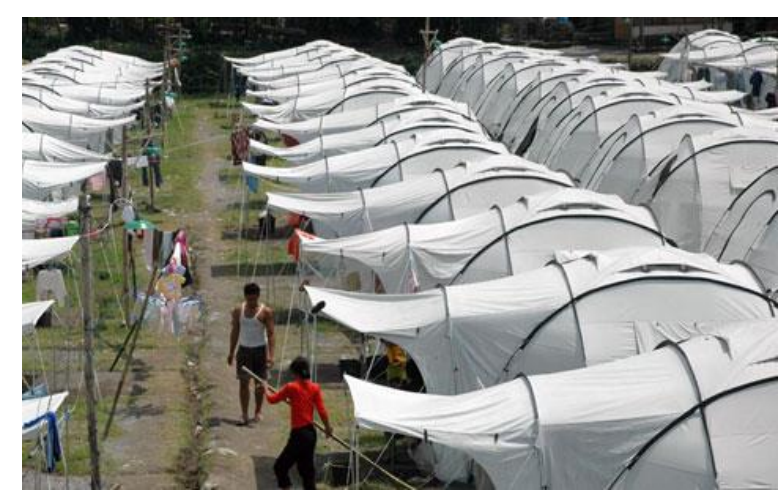

Source: http://mobile.seruu.com/utama/nasional/artikel/bnpbbangun-shelter-bencana-di-pandeglang

Figure 2. Temporary shelter built by National Disaster Management Agency in Pandeglang, Banten

The permanent houses are permanent accommodations built in the location of the victims' destroyed houses, or in other prepared area since the prior location is inhabitable, but they are planned for permanent dwellings.

For low-income community, the process of recovering their house and life takes more time and depends solely on the support from the government or humanitarian organisations, since they do not have adequate resources. Thus, the transitional house should be comfortable to live for several months, before the completion of their permanent houses. Although temporary, these houses should be designed to suit the habit and culture of the victims, to acelerate the revitalisation process of the victims' life, not only physically but psychologically.

Aside from the importance of a transitional house, a permanent house to replace the lost of disaster victims' house is compulsory. This permanent house should be designed according to the need and conditions of the victims. It is preferable if the house capital is small, but the house can be expanded later when the victims have better economics. Thus, an incremental construction is the most appropriate solution (Ferrajuanie, 2014).

\section{THE CORE HOUSE}

The incremental house concept, well-known as the core housing was introduced by the United Nations to the underdeveloped areas in 1960s to provide an organised, cheap, and practical solution for the urban area in poor countries (Napier, 2002). The core house is a simple shelter built with a limited budget, and then expanded room by room or part by part along with the economic growth of the family, until the house fulfils the need of whole family. The core house performs as a transitional shelter but permanent construction. It accommodates the future possibility to expand the house according to the occupant's spatial needs (Ikaputra, 2008). Nowadays, this core house concept is applied widely, not only by poor community and developing countries, since this concept means that the house grows according to the financial condition and the growing space needed by the owner. Abrams mentioned the construction method of the core house as instalment construction or building serially (Napier, 2002).

Habitat for Humanity International (2014), an international humanitarian organisation uses the core house model to replace the destroyed homes of the earthquake victims in Haiti. The house is a permanent structure with room to grow to accommodate future expansion of the house when the family's economics condition is improved.

Core house concept was also used in the house reconstruction effort after the Yogyakarta Earthquake in 2006. The core house is $18 \mathrm{~m}^{2}$ (consisting of two modules of $3 \mathrm{~m} \times 3 \mathrm{~m}$ ) and constructed with reinforced concrete frame, brick masonry wall and a simple gable roof (Ikaputra, 2008).

\section{FIRST STAGE - THE TRANSITIONAL HOUSE}

This project starts with the process of designing a transitional house. The house is planned $6 \mathrm{~m}$ length and $3 \mathrm{~m}$ wide, with the lay-out consisting of a living room and a bedroom (Figure 3 ). In the design process, $18 \mathrm{~m}^{2}$ was agreed as the plan size, to comply the PMI standard for a minimum plan size for comfortable living unit. A partition separates the private space (bedroom) from a more public area in the house to accommodate more private activities, such as sleeping or breastfeeding. $6 \mathrm{~m}^{2}$ was considered as a minimum room size for comfortable private room.

The proposed design uses bamboo construction for the structural main frame, roof structure, doors and windows' frames. These bamboo components are assembled using some traditional bamboo joints, such as fish-mouth joints, lashing joints (with coco fibre, rattan or rope), and plug-in joints (Widyowijatnoko, 2012). The base of the structure is constructed with stone footing (Figure 4) and rollag. The wall is covered with woven bamboo known as 'gedek', while the roof covering is thatched roof using 'rumbia' (sago palm leaves).

Bamboo construction is less durable compared to the use of concrete frame with masonry wall construction. However, bamboo was chosen, considering that bamboo is a local material available in Jember and surroundings, and that the transitional house is not 
a permanent shelter and only planned to be used not more than one year during the preparation of the permanent housing. To help the volunteers of PMI (Indonesian Red Cross Organization) building the house, a manual was prepared to direct step-by-step construction of the house, and trainings were held. The house prototype was built on May 2013 as shown in Figure 5.

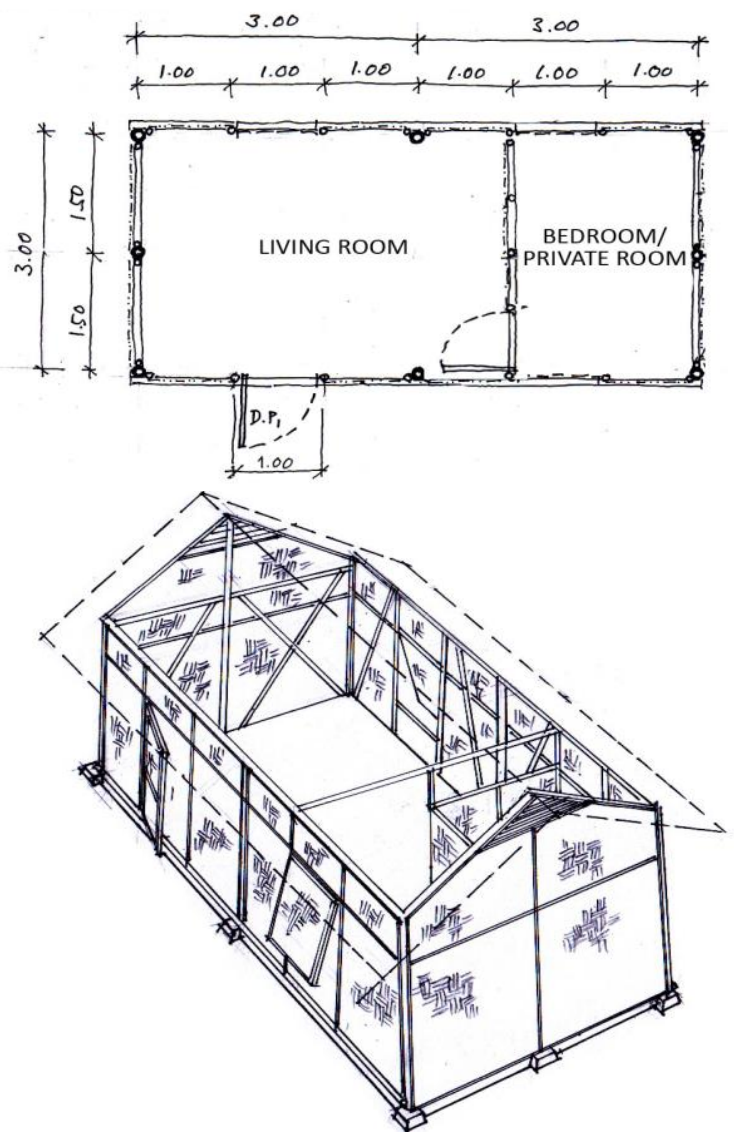

Figure 3. Design of the transitional house

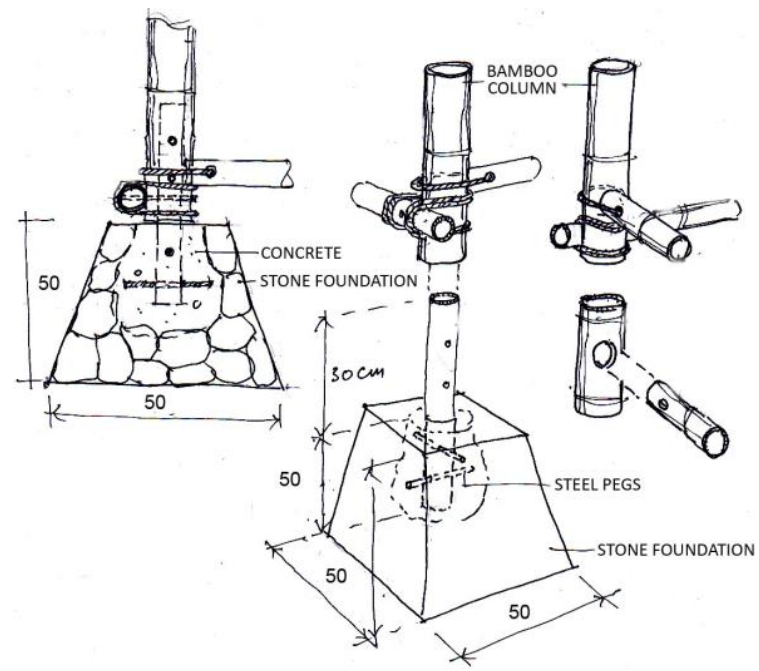

Figure 4. Detail of the substructure

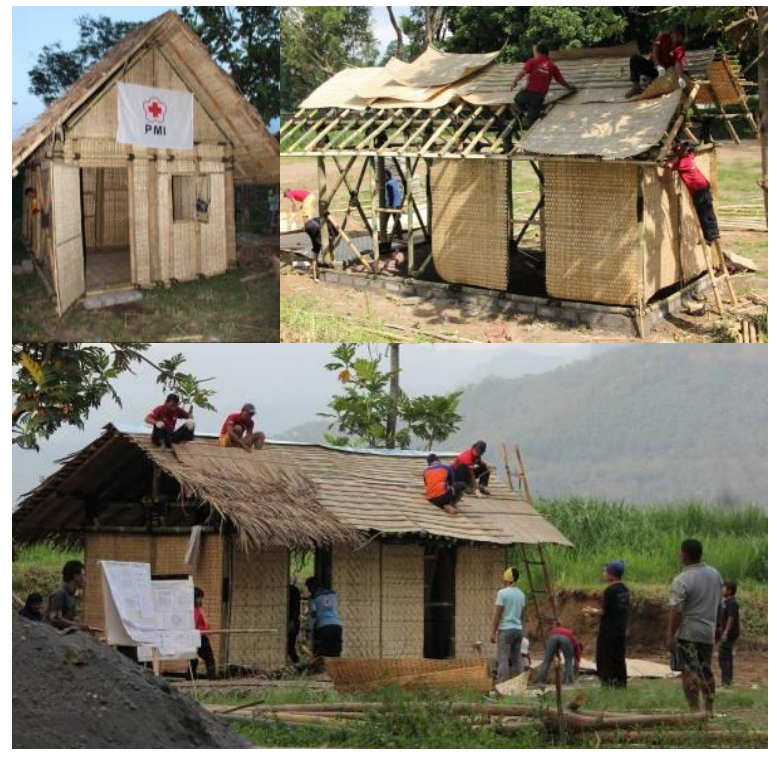

Figure 5. Prototype of PMI's Transitional house for disaster victims built in Selorejo, Malang

\section{BAMBOO CONSTRUCTION}

The use of bamboo construction has increased a lot these days along with the public awareness towards environmental crisis. Bamboo is one of the most sustainable materials. Bamboo trees have widest range habitats and grow very fast, some species even grow one and a half meter each day. Bamboo is renewable material, it endures through time and survives through various weather conditions (Environmental Bamboo Foundation, n.a.). As a structural material, bamboo is an efficient material. It is elastic and it has a tensile strength up to three times higher than timber, and similar to than steel (Gutu, 2013). Bamboo is also a versatile material which can be used not only as a structural element, but also as floor, wall, roof and even furniture.

The use of bamboo construction in this transitional house compared to timber or masonry construction has several benefits:

- Local material

Bamboo is considered as a local material in Jember, it is widely available, and thus its usage minimise the cost of transporting the material into the area.

- Utilising the available labour and skill

Since bamboo is a local material, bamboo construction has been known very well among the community. Therefore, the local people can involve in the construction process.

- Sustainable construction

Bamboo is a natural material, easily found around the area, and does not have hazardous impact to the environment 
- Minimise the cost of construction

The cost estimation of the bamboo construction and the timber construction shows that the construction of one transitional house with bamboo construction costs 8,5 million rupiahs, while if the house is built with timber construction it will cost around 12,5 million.

\section{SECOND STAGE - THE INCREMENTAL HOUSE}

The incremental house concept is proposed as a solution for the permanent house. Thus, it is important to find a proper model of the core house, and to prepare the development scheme of the core house. To find the core house model, evaluation was carried out towards the transitional house model:

- The house lay-out

The house is designed using two modules of $3 \mathrm{~m} \mathrm{x}$ $3 \mathrm{~m}$, similar to the core house design used in postearthquake recovery in Yogyakarta (Ikaputra, 2008).

- Bamboo construction

The use of bamboo construction is appropriate since bamboo is considered as local material available in Jember, and the community is very familiar with the construction.

However, as a permanent construction, bamboo is weak in term of the fire resistance. Moreover, as most low-income community, the local people has perception that bamboo construction looks cheap, traditional and less modern, thus for a permanent house they tend to prefer a masonry or plastered wall.

- The gable roof orientation

The roof orientation of the transitional house is the most efficient and economical solution. Nevertheless, the roof orientation limits the possibility for the house expandability.

Based on the evaluation of the first model, the incremental house model is designed. The core house model also comprises of two modules of $3 \mathrm{~m} \times 3 \mathrm{~m}$ plan, but the roof gable orientation is rotated so that the house can easily be expanded backward to form 4 modules or 6 modules arrangement. Figure 6 shows the core house unit and the expansion plan.

To increase the fire resistance of the structure and to provide possibility to improve the appearance of the house, the wall is planned using woven bamboo covering which can be adjusted into a plastered bamboo wall. Plastered bamboo wall construction is developed based on the colonial plastered bamboo wall researches which last 90 years (Widyowijatnoko
\& Mustakim, n.a.). The plastered bamboo wall construction is a woven bamboo wall with bamboo frame which is then plastered to improve the strength of the structure, the fire resistance and the appearance or the expression of the wall. This construction is very suitable for a cheap house alternative, and thus appropriate to be used in the transitional houses for disaster victims which can be developed into permanent houses in the future. Figure 7 shows an example of woven bamboo wall which then convert into a plastered bamboo wall.

To accommodate the plastered bamboo construction, in preparation to support additional structural loads, the bamboo columns are designed to stand on concrete columns. Underneath the woven bamboo wall, brick wall is designed as the base structure for moist reduction and floods anticipation. Thus, to support larger structural loads, this incremental structure uses stone footing continuously along the wall (Figure 8), different with the combination of stone footing and rollag used in the transitional shelter.
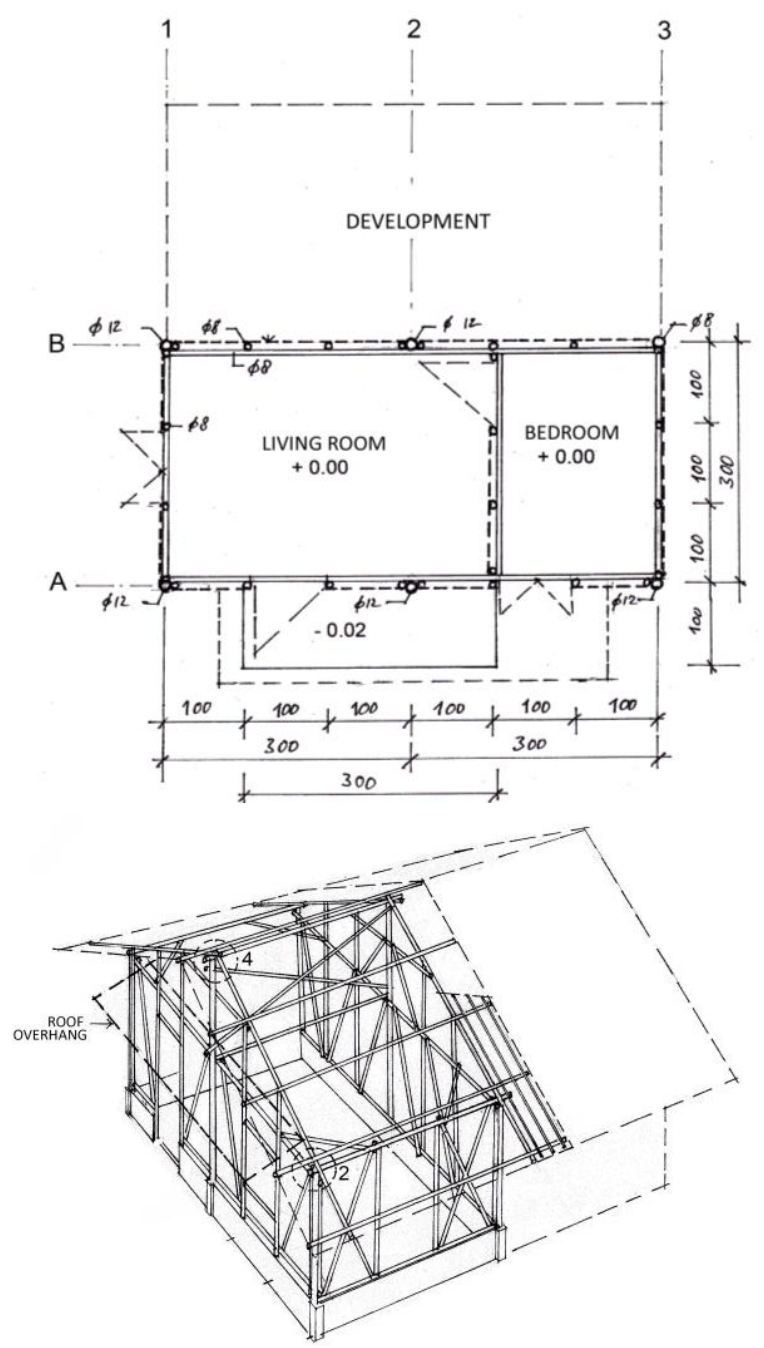

Figure 6. The incremental house plan \& perspective 


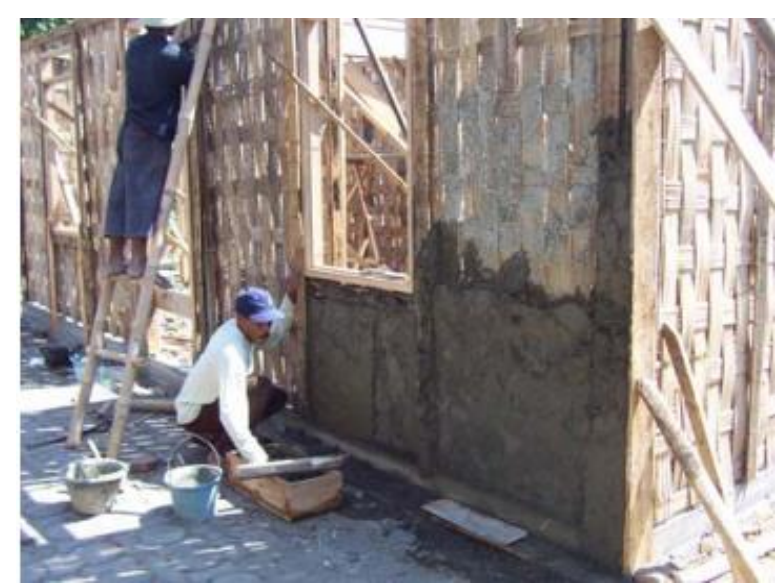

Source: Widyowijatnoko \& Mustakim, n.a.

Figure 7. The making of plastered bamboo wall
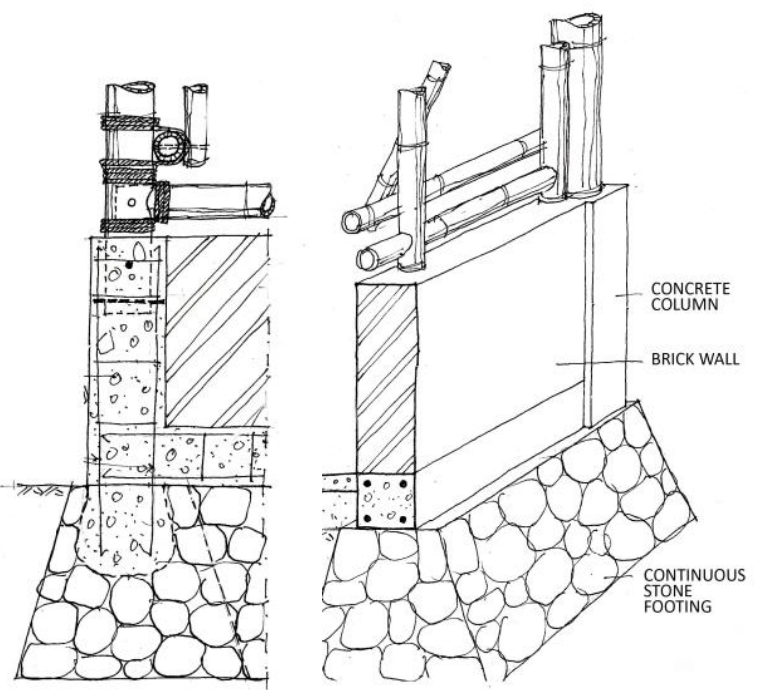

Figure 8. The continuous stone footing

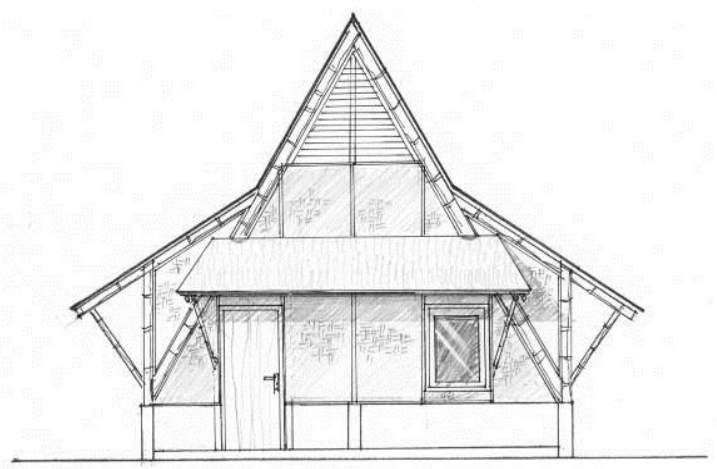

Figure 9. The second alternative of the core house

An alternative design of the core house was also produced to provide variation in the architectural form of the incremental house. The second alternative is designed with variation at the form of the house roof (Figure 9). In here, even though the construction cost slightly higher, but the design shows the aesthetic aspect of the bamboo construction. The purpose is to educate the local community regarding the potency of bamboo as structural material which is not only strong and versatile, but also aesthetic.

\section{CONCLUSION}

In designing a transitional shelter for disaster victims, an incremental house approach is used, to provide both transitional houses and permanent houses. This incremental concept is considered as an empathic approach towards the victims' condition and needs:

- The use of core house concept is appropriate to the limited budget of the disaster victims. With this concept, funding from PMI or other humanitarian organisation/government can help more victims. However, later on, when the victims have settled and their financial condition increases, they can easily expand the house.

- The incremental house model accommodates the construction development from the woven bamboo into plastered bamboo wall. Thus, it presents the possibility for the house to grow not only in size, but also in appearance, to express better quality or more decent house. This is required to anticipate the bad perception about bamboo construction among the low-income community.

- The roof variation in the last model is beneficial to educate the community regarding the aesthetic potential of the bamboo construction. This is important to promote the use of bamboo construction, considering bamboo is one of the most sustainable material and its usage is beneficial in anticipate the environmental crisis at present time.

\section{REFERENCES}

Environmental Bamboo Foundation (n.a.). Why Bamboo? Here's Why. Retrieved from www.bamboocentral.org

Ferrajuanie, A. (2014). Transitional Shelter: Basic Principles of Transitional Shelter. East Java Red Cross Organization.

Gutu, T. (2013). "A Study on the Mechanical Strength Properties of Bamboo to Enhance Its Diversification on Its Utilization". International Journal of Innovative Technology and Exploring Engineering, 2(5), p. 314-319.

Habitat for Humanity International (2014). Core Houses. Retrieved from www.habitat.org/ disaster/active_programs/Core_houses.aspx 
Ikaputra (2008). "Core House: A Structural Expandibility for Living, Study Case of Yogyakarta Post Earthquake 2006". Journal Dimensi Teknik Arsitektur, 36(1), p. 10-19.

Napier, M. (2002). Core Housing, Enablement and Urban Poverty: The Consolidation Paths of Households Living in Two South African Settlement. UK: University of Newcastle.

Quarantelli, E.L. (1982). Sheltering and Housing: After Major Community Disaster. Newark,
Delware: University of Delaware, Disaster Research Center.

Widyowijatnoko, A. (2012). Traditional and Innovative Joints in Bamboo Construction. Aachen: Faculty of Architecture, RWTH Aachen University.

Widyowijatnoko, A. \& Mustakim (n.a.). Plastered Bamboo Wall Construction. Bandung: Architecture Department, Bandung Institute of Technology. 